\title{
ANALISIS KINERJA KEUANGAN BANK SEBELUM DAN SESUDAH DIAKUISISI OLEH INVESTOR ASING: STUDI EMPIRIS PADA BANK CENTRAL ASIA DAN BANK NIAGA
}

\author{
Yen Sun; Laurentia Dermawan \\ Jurusan Akuntansi, Fakultas Ekonomi dan Bisnis, Universitas Bina Nusantara \\ Jln. K.H. Syahdan No. 9, Palmerah, Jakarta Barat 11480 \\ ysun@binus.edu, rakuen_freak@yahoo.com
}

\begin{abstract}
Banking industry is one of the most influence factors in the economy growth of one country. However, during 1997-1998 Indonesia banking industry went through hard times because of economic crisis. After that years, many banks were liquidated and restructured. The interesting part is through the restructuring process, several bank acquired by foreign investor and became the foreign-domestic bank. In 2010, some of those banks were in the 10 biggest banks in Indonesia based on asset. Hence, the writer interesting to compare the bank's financial performance before and after being acquired using two banks as samples of empirical study. Data is based on financial statements published by the companies and Central Bank of Indonesia in 1995-1996, and 2003-2004. Two sample of banks have been selected based on several criteria, they are BCA and Bank Niaga. To analyse their financial performance, several analysis tools will be using, specifically CAMELS (CAR, NPL, NIM, BOPO, LDR minus mangement and sensitivity). The result of the study observed that after being acquired, financial performance of BCA and Niaga Bank is getting better in CAR, NIM, BOPO, but NPL and LDR is less favorable for BCA and so NPL is less favorable for Niaga Bank. Moreover, in terms of profitability analysis, both banks shows better performance. While, the result of credit analysis indicates that the credit risk for both banks is in the stable range at CCC.
\end{abstract}

Keywords: CAMELS, profitability analysis, credit analysis, kinerja keuangan

\begin{abstract}
ABSTRAK
Perbankan merupakan salah satu aspek yang paling berpengaruh dalam pertumbuhan perekonomian suatu negara. Namun demikian, di Indonesia sendiri, pada tahun 1997-1998 industri perbankan terkena dampak krisis ekonomi. Pasca krisis ekonomi tersebut, banyak bank yang dilikuidasi karena bangkrut, dan sisanya tidak luput dari restrukturisasi seperti diakuisisi oleh investor asing dan berubah menjadi bank campuran. Pada tahun 2010, bank campuran tersebut masuk dalam daftar 10 bank terbesar berdasarkan aset. Oleh karena itu, penulis tertarik untuk membandingkan kinerja keuangan bank campuran sebelum dan sesudah diakuisisi oleh investor asing dengan menggunakan dua bank sebagai bahan studi empiris. Data yang digunakan dalam penelitian ini berupa laporan keuangan publikasi yang dikeluarkan oleh BI maupun bank yang bersangkutan tahun 1995, 1996, 2003, dan 2004. Peneliti meneliti dua sampel bank sesuai dengan kriteria yang telah ditetapkan yakni BCA dan Bank Niaga, dengan menggunakan tiga metode yaitu CAMELS (CAR, NPL, NIM, $B O P O, L D R$. Hasil analisis menunjukkan bahwa dengan metode CAMELS terjadi peningkatan kinerja keuangan yang semakin baik kecuali untuk NPL dan LDR yang kurang baik bagi BCA dan NPL yang juga kurang baik untuk Bank Niaga sesudah diakuisisi oleh investor asing. Dari segi profitabilitas, kedua bank menunjukkan kinerja yang membaik setelah diakuisisi. Selanjutnya, dengan Credit Analysis, risiko kredit kedua bank dinilai cenderung tetap berada di peringkat CCC baik sebelum maupun sesudah diakuisisi oleh investor asing.
\end{abstract}

Kata kunci: CAMELS, analisis profitabilitas, analisis kredit, financial performance 


\section{PENDAHULUAN}

Tipikal negara berkembang seperti Indonesia adalah adanya saving investment gap yang tidak dapat ditutupi oleh budget pemerintah, sehingga keterlibatan bank sebagai penghimpun dan penyalur dana sangat berperan bagi pembangunan ekonomi negara. Menurut data statistik yang tercatat di BEI tahun 2010, industri perbankan menguasai 23.4\% dari market capitalization keseluruhan industri di Indonesia (www.idx.co.id). BI merilis sepuluh peringkat bank terbesar pada tahun 2010 yang menguasai 63.5\% pangsa pasar aset perbankan nasional. Enam dari sepuluh bank tersebut merupakan bank pemerintah dengan total aset Rp 1,113.98 triliun atau sebesar 41.25\% dari pangsa pasar aset perbankan nasional. Sedangkan lima di antaranya merupakan bank bank campuran dengan total aset Rp 600.77 triliun yang menguasai pangsa pasar aset perbankan nasional sebesar 22.25\%.

Ditambah dengan diluncurkannya peraturan Arsitektur Perbankan Indonesia (API) yang dirilis oleh BI, yang mewajibkan bank untuk memenuhi jumlah minimum aset sebesar Rp 100 miliar pada tahun 2010, perkembangan bank campuran terhadap total aset perbankan meningkat secara signifikan. Hal ini dapat terlihat dari porsi kepemilikan asing terhadap industri perbankan nasional yang mendekati 50\%, atau tepatnya sebesar 47.02\% pada tahun 2010 (Akbarwati, 2010).

Tetapi, apabila menilik beberapa tahun ke belakang, nyatanya perbankan nasional tidak bertumbuh dengan mudah. Salah satu faktor yang signifikan ialah krisis ekonomi di era 1990-an akhir, yang juga menjalar ke sektor perbankan. Krisis perbankan tidak semata-mata terjadi karena krisis ekonomi, namun juga dipengaruhi oleh faktor lainnya. Melihat regulasi perbankan sebelum dan sesudah krisis tahun 1998 terjadi, dapat diketahui betapa lemahnya pengawasan peraturan yang dibuat oleh pemerintah mengenai perbankan di Indonesia. Seperti yang dijelaskan oleh Suta \& Soebowo (2003), Paket deregulasi pada Oktober (Pakto) 1988 memuat beberapa aspek penting, salah satunya ialah kemudahan pendirian bank baru. Hanya dengan Rp 10 miliar, seseorang dapat mendirikan bank devisa domestik, dan dengan Rp 50 miliar dapat membentuk bank campuran. Dengan dimudahkannya pendirian bank baru, pertumbuhan perbankan pun melonjak.

Kebutuhan akan dana yang besar sebagai modal bank menjadi peran yang penting dalam kelangsungan hidup bank tersebut. Pemerintah akhirnya membuat perubahan ketentuan mengenai kepemilikan asing terhadap bank campuran yang ada di Indonesia, yakni maksimum sebesar 99\%, naik dari ketentuan sebelumnya sebesar 85\%. Dengan memasukkan bank campuran sebagai bagian dari kelompok bank asing, maka porsi total aset bank asing terhadap total aset perbankan pun meningkat dari 7.74\% pada tahun 1996, menjadi 12.75\% pada Mei 2004.

Semakin besarnya kepemilikan investor asing terhadap perbankan nasional dari tahun ke tahun membuat pertanyaan mengenai apakah kinerja keuangan bank-bank yang telah diakuisisi oleh investor asing menunjukkan peningkatan atau penurunan bila dibandingkan dengan sebelum diakuisisi, yakni sebelum krisis 1998 terjadi. Dan untuk menjawab pertanyaan tersebut, penelitian ini berfokus pada analisis perbandingan kinerja keuangan bank sesudah dan sebelum diakuisisi oleh investor asing, dengan menggunakan metode CAMELS, Profitability Analysis, serta Credit Analysis untuk menilai tingkat profitabilitas dan peringkat obligasi bank.

\section{Studi Pustaka}

Penelitian mengenai kinerja bank sudah banyak dilakukan oleh peneliti-peneliti sebelumnya. Bonin, Hasan, \& Wachtel (2003) dalam paper yang berjudul Bank Performance, Efficiency, and Ownership in Transition Countries menggunakan 220 bank yang terdapat di 11 negara Eropa sebagai sampel, dan melakukan analisis dengan membandingkan ROA untuk menilai tingkat profitabilitas dan efficiency score untuk menilai efisiensi bank periode 1996-2000, serta melakukan observasi terhadap 
ekonomi makro tiap negara. Mereka menjelaskan bahwa kinerja bank-bank yang kepemilikannya mayoritas dimiliki oleh investor asing memiliki tingkat profitabilitas dan ROA yang lebih tinggi dibandingkan dengan bank-bank domestik milik pemerintah, namun tidak diiringi dengan tingkat biaya yang efisien.

Penelitian sejenis pun dilakukan oleh Chantapong (2005) dengan judul Comparative Study of Domestic and Foreign Bank Performance in Thailand: The Regression Analysis. Ia menggunakan 23 bank baik bank domestik, bank yang mayoritas dimiliki investor asing, maupun cabang dari bank asing yang ada di Thailand, untuk 6 periode penelitian, yakni 1995-2000. Sedangkan metode yang digunakan ialah analisis rasio dari balance sheet dan income statement.

Chantapong (2005) melakukan penelitian dengan tujuan untuk membandingkan kinerja antara bank domestik dan bank campuran terutama dalam tingkat profitabilitasnya. Adapun kesimpulan yang dihasilkan nyatanya memiliki kesamaan dengan Bonin, Hasan, dan Wachtel, yaitu profitabilitas bank campuran menunjukan tingkat yang lebih tinggi dibandingkan dengan bank domestik, yang tidak dikuasai oleh investor asing.

Untuk melihat apakah partisipasi investor asing dalam perbankan Indonesia, terutama bankbank swasta yang telah diakuisisi oleh asing juga memiliki dampak yang serupa, maka penelitian ini berfokus pada analisis sejenis dengan beberapa metode lain (CAMELS, Profitability Analysis, Credit Analysis) untuk membandingkan kinerja keuangan bank itu sendiri dalam periode waktu yang berbeda, di saat kondisi bank diasumsikan sehat, yakni sebelum dan sesudah krisis terjadi serta sebelum dan sesudah akusisi dilakukan oleh investor asing.

\section{METODE}

Jenis data yang digunakan dalam penelitian ini adalah jenis data kualitatif. Sedangkan sumber data yang digunakan berupa data sekunder yang berasal dari laporan keuangan yang dikeluarkan oleh Bank Indonesia, yaitu laporan keuangan dua tahun sebelum krisis terjadi serta belum diakuisisi oleh investor asing (1995 dan 1996) dan dua tahun sesudah diakuisisi oleh investor asing (2003 dan 2004), dengan asumsi bahwa periode penelitian ialah pada saat kondisi bank sehat.

Berdasarkan sepuluh peringkat bank terbesar tahun 2010 yang menguasai 63.5\% pangsa pasar aset perbankan nasional, yang dirilis oleh Bank Indonesia, peneliti menggunakan dua sampel bank terbesar di antaranya yang telah diakuisisi oleh investor asing dan bukan merupakan gabungan dari beberapa bank, dengan periode pengakuisisian yang sama, yakni pada tahun 2002. Kedua bank tersebut terkena dampak yang sama akibat krisis yang terjadi di tahun 1997, namun berhasil bangkit dan pulih.

Dengan menggunakan metode purposive sampling, maka bank yang terpilih sebagai sampel adalah: (1) Bank Central Asia, dengan total aset sebesar Rp 305.16 triliun atau dengan kata lain menguasai 11.30\% pangsa pasar aset perbankan nasional untuk tahun 2010; dan (2) Bank Niaga, yang sekarang bernama Bank CIMB Niaga dengan total aset sebesar Rp 126.96 triliun atau dengan kata lain menguasasi 4.70\% pangsa pasar aset perbankan nasional untuk tahun 2010.

Selanjutnya kedua sampel bank tersebut akan dinilai dengan menggunakan metode CAMELS (CAR, NPL, NIM, BOPO, LDR, tanpa menilai aspek Manajemen dan Sensitivitas terhadap Risiko Pasar), Profitability Analysis (Net Profit Margin, ROE, ROA), dan Credit Analysis (EBIT Interest Coverage, Return on Capital, Total Debt to Capital) untuk membandingkan kinerja keuangan bank sebelum dan sesudah diakuisisi oleh investor asing. 


\section{HASIL DAN PEMBAHASAN}

\section{Penilaian Kinerja Keuangan Bank Menurut Metode CAMELS}

Mengacu pada Peraturan Bank Indonesia Nomor 6/10/PBI/2004 tanggal 12 April 2004, terdapat berbagai metode untuk mengukur kesehatan suatu bank. Salah satunya adalah dengan analisis CAMELS. Unsur-unsur penilaian dalam analisis CAMELS adalah capital, assets, management, earnings, dan liquidity.

\section{Capital (Permodalan)}

Penilaian didasarkan kepada permodalan yang dimiliki oleh salah satu bank. Salah satu penilaian adalah dengan metode CAR (capital adequacy rasio), yaitu dengan cara membandingkan modal terhadap aktiva tertimbang menurut risiko (ATMR).

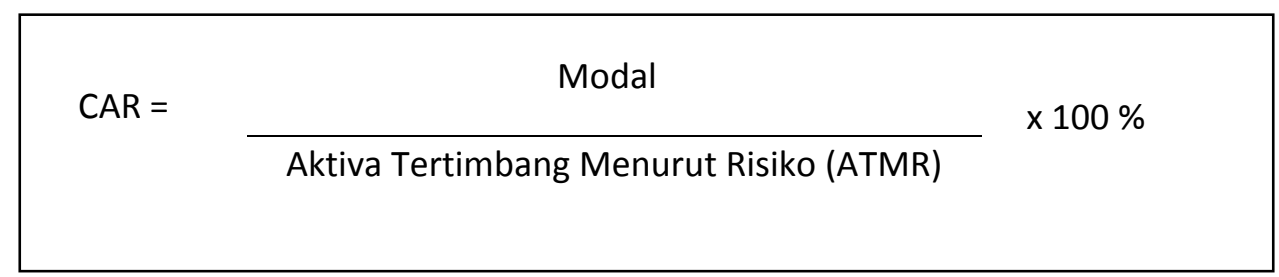

Berdasarkan ketentuan BI, bank yang dinyatakan sebagai bank sehat harus memiliki CAR minimal 8\%. Bila bank memiliki CAR di bawah 8\%, maka bank tersebut memerlukan modal tambahan dari pemegang saham atau pun merger dengan bank yang memiliki CAR yang tinggi.

\section{Assets (Kualitas Aset)}

Salah satu rasio yang dapat digunakan untuk menilai kualitas aset suatu bank ialah Non Performing Loan (NPL). NPL ialah rasio untuk menghitung tingkat kredit bermasalah yang dimiliki oleh bank terhadap tingkat kredit yang diberikan kepada pihak ketiga, namun tidak termasuk tingkat kredit yang diberikan kepada bank lain. Kredit bermasalah dapat dikualifikasikan sebagai kredit kurang lancar, diragukan, dan macet.

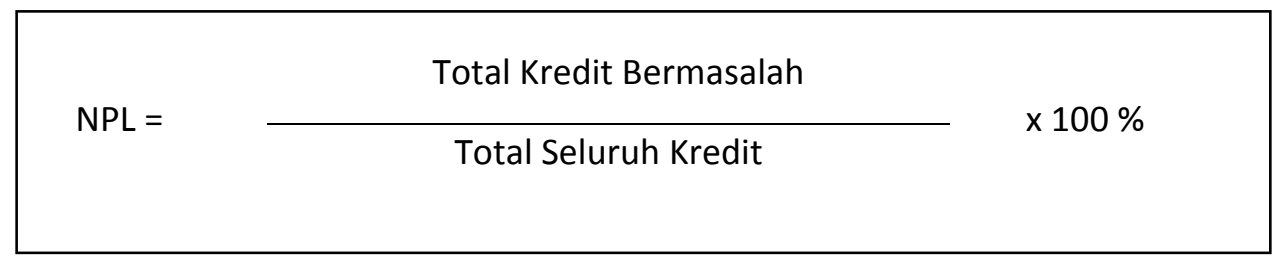

Berdasarkan SE Bank Indonesia No. 6/23/DPNP tanggal 31 Mei 2004, NPL yang ditetapkan oleh BI maksimum sebesar 5\%. Apabila NPL bank semakin rendah, maka semakin baik karena jumlah kredit macet pada bank tersebut semakin kecil, dan sebaliknya.

\section{Management (Manajemen)}

Penilaian terhadap faktor manajemen meliputi penilaian terhadap komponen-komponen adalah: (1) kualitas manajemen umum dan penerapan manajemen risiko; dan (2) kepatuhan bank terhadap ketentuan yang berlaku dan komitmen kepada Bank Indonesia dan atau pihak lainnya. 


\section{Earning (Rentabilitas)}

Penilaian didasarkan pada rentabilitas suatu bank yang dilihat kemampuan suatu bank dalam menciptakan laba. Adapun beberapa rasio yang digunakan untuk menilai rentabilitas suatu bank ialah: (1) NIM (Net Interest Margin); (2) BOPO (Beban Operasional dibandingkan dengan Pendapatan Operasional).

NIM digunakan untuk mengetahui pendapatan bunga bersih dalam 12 bulan yang mampu diperoleh oleh bank, dibandingkan dengan rata-rata aktiva produktif bank.

NIM $=\frac{\text { Pendapatan Bunga Bersih }}{\text { Rata-Rata Aktiva Produktif }} \times 100 \%$

Untuk mengetahui tingkat perbandingan antara biaya operasional yang ditanggung bank dengan pendapatan operasional yang diperoleh bank, maka dapat digunakan rasio BOPO. Semakin kecil angka rasio BOPO, maka semakin baik kondisi bank tersebut.

BOPO $=\frac{\text { Beban Operasional }}{\text { Pendapatan Operasional }} \times 100 \%$

\section{Liquidity (Likuiditas)}

Untuk menilai tingkat likuiditas suatu bank, dapat digunakan Loan To Deposit Ratio (LDR). Rasio ini menggambarkan kemampuan bank membayar kembali kewajiban kepada para nasabah yang telah menanamkan dananya dengan kredit-kredit yang telah diberikan kepada para debiturnya.

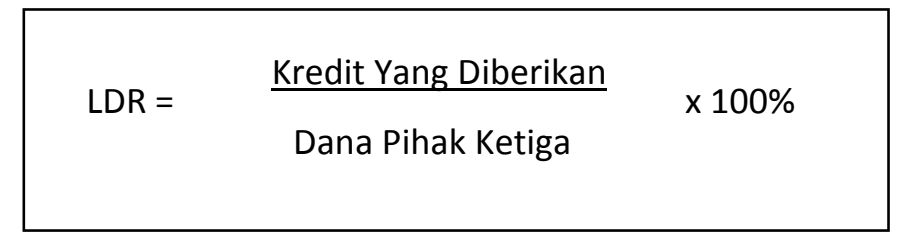

Jumlah kredit yang diberikan dalam rumus di atas adalah kredit yang diberikan bank yang sudah direalisir / ditarik / dicairkan. Dana pihak ketiga meliputi simpanan masyarakat yang berupa giro, tabungan dan deposito. LDR yang tinggi menunjukkan profit margin yang lebih tinggi, namun memiliki risiko yang juga tinggi. LDR yang rendah juga tidak selalu menunjukkan kinerja yang bagus. Walaupun risiko yang ditanggung lebih kecil, namun LDR juga mengindikasikan bank tidak mampu memaksimalkan profitnya.

Sensitivity to Market Risk (Sensitivitas Terhadap Risiko Pasar). Penting untuk melihat sensitivitas terhadap risiko market supaya tujuan untuk memperoleh laba dapat tercapai dan kesehatan bank pun terjamin. Ada pun risiko yang harus dihadapi ialah risiko lingkungan, risiko manajemen, risiko penyerahan, dan risiko keuangan. Penilaian terhadap faktor sensitivitas terhadap risiko pasar meliputi penilaian terhadap komponen-komponen seperti (1) kemampuan modal Bank dalam mengcover potensi kerugian sebagai akibat fluktuasi (adverse movement) suku bunga dan nilai tukar; (2) kecukupan penerapan manajemen risiko pasar. 
Adapun kriteria yang digunakan untuk menilai kinerja keuangan bank menurut metode CAMELS ialah seperti yang dijelaskan dalam tabel berikut:

Tabel 1. Kriteria Penilaian Kinerja Keuangan Bank Berdasarkan Metode CAMELS

\begin{tabular}{ccc}
\hline Aspek & Kondisi & Keterangan \\
CAR & Meningkat & Semakin baik \\
NPL & Menurun & Semakin baik \\
NIM & Meningkat & Semakin baik \\
BOPO & Menurun & Semakin baik \\
LDR & Antara $78 \%-100 \%$ & Semakin baik \\
\hline
\end{tabular}

\section{Penilaian Kinerja Keuangan Bank Menurut Profitability Analysis}

Salah satu tolak ukur yang paling diminati oleh para investor dalam menilai kesehatan suatu bank dilihat dari tingkat profitabilitas yang dihasilkan. Tingkat profitabilitas merupakan tingkat keuntungan yang didapat suatu bank sebagai hasil dari kinerja keuangan mau pun operasionalnya selama periode tertentu. Mengacu pada Kasmir (2008), ada pun beberapa rasio rentabilitas yang sering kali disebut profitabilitas.

Rasio Net Profit Margin (NPM) ini digunakan untuk mengukur kemampuan operasi pokok bank dalam menghasilkan net income.

$$
\text { Net Profit Margin }=\quad \frac{\text { Net Income }}{\text { Operating Income }} \quad x 100 \%
$$

Return on Equity (ROE) digunakan untuk membandingkan laba bersih perusahaan dibandingkan dengan total ekuitas yang dimilikinya.

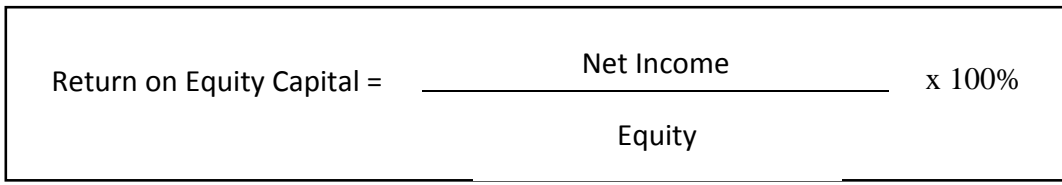

Rasio Return on Assets (ROA) ini menunjukkan efisiensi bank dalam menggunakan asetnya untuk menghasilkan laba.

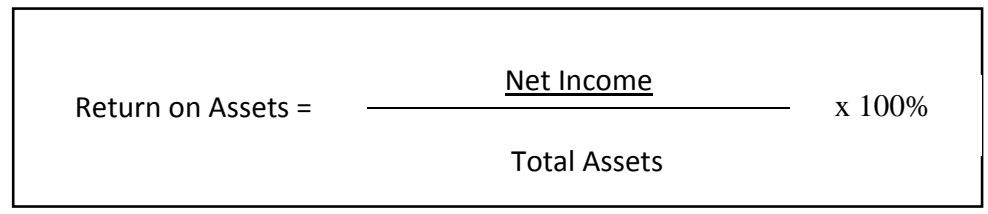

Adapun kriteria yang digunakan untuk menilai kinerja keuangan bank menurut Profitability Analysis ialah seperti yang dijelaskan dalam tabel berikut: 
Tabel 2. Kriteria Penilaian Kinerja Keuangan Bank Berdasarkan Profitability Analysis

\begin{tabular}{ccc}
\hline Aspek & Kondisi & Keterangan \\
NPM & Meningkat & Semakin baik \\
ROE & Meningkat & Semakin baik \\
ROA & Meningkat & Semakin baik \\
\hline
\end{tabular}

\section{Penilaian Kinerja Keuangan Bank Menurut Credit Analysis}

Indonesia sebagai negara berkembang pun tidak lepas dari penilaian rating yang dilakukan oleh Standard \& Poor’s yang bekerja sama dengan PT. Pefindo. Dijelaskan oleh Farid dalam artikel Obligasi RI: MenKeu Tak Risaukan Peringkat S\&P (kompas.com, 1996). Pada tahun 1995 dan 1996, Indonesia menempati peringkat BBB menurut Standard \& Poor's, yaitu dinilai memiliki kemampuan untuk memenuhi kewajiban keuangan dan penarikan dana pada waktunya, namun sangat rentan terhadap perubahan kondisi ekonomi. Sedangkan pada tahun 2003, peringkat Indonesia untuk debt ratingnya menurun menjadi B. Namun pada 2004, Indonesia mengalami sedikit perkembangan menempati $\mathrm{B}+$. Hal tersebut menunjukkan kualitas bonds Indonesia yang dinilai masih berkualitas menengah rendah dan cenderung spekulatif.

Menurut Standard and Poor's (lembaga khusus di U.S. yang memberikan debt ratings perusahaan), ada beberapa rasio keuangan yang dapat digunakan untuk menilai peringkat suatu perusahaan.

Rasio EBIT Interest Coverage ini digunakan untuk menilai seberapa besar kemampuan earning yang diperoleh oleh perusahaan sebelum dipotong pajak dan bunga, dapat mengatasi jumlah beban bunga yang ada.

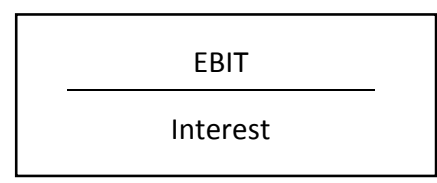

Rasio Return on Capital ini digunakan untuk menilai seberapa besar earning yang diperoleh oleh perusahaan sebelum dipotong pajak dan bunga, bila dibandingkan dengan total modal dan hutang yang dimiliki peerusahaan.

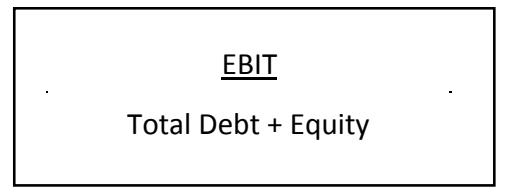

Rasio Total Debt to Capital ini digunakan untuk menilai seberapa besar porsi hutang bila dibandingkan dengan total modal keseluruhan yakni total hutang dan ekuitas perusahaan.

Total Debt

Total Debt + Equity 
Tabel 3. Adjusted Key Industrial Financial Ratios (1998 - 2000)

\begin{tabular}{|l|c|c|c|c|c|c|c|}
\hline & AAA & AA & A & BBB & BB & B & CCC \\
\hline EBIT Interest Coverage (x) & 21.4 & 10.1 & 6.1 & 3.7 & 2.1 & 0.8 & 0.1 \\
\hline Return on Capital (\%) & 34.9 & 21.7 & 19.4 & 13.6 & 11.6 & 6.6 & 1 \\
\hline Total Debt to Capital (\%) & 22.9 & 37.7 & 42.5 & 48.2 & 62.6 & 74.8 & 87.7 \\
\hline
\end{tabular}

Sumber: Standard \& Poor’s - Corporate Ratings Criteria 2000

Tabel 4. Adjusted Key Industrial Financial Ratios (2002 - 2004)

\begin{tabular}{|l|c|c|c|c|c|c|c|}
\hline & AAA & AA & A & BBB & BB & B & CCC \\
\hline EBIT Interest Coverage (x) & 23.8 & 19.5 & 8 & 4.7 & 2.5 & 1.2 & 0.4 \\
\hline Return on Capital (\%) & 27.6 & 27 & 17.5 & 13.4 & 11.3 & 8.7 & 3.2 \\
\hline Total Debt to Capital (\%) & 12.4 & 28.3 & 37.5 & 42.5 & 53.7 & 75.9 & 113.5 \\
\hline
\end{tabular}

Sumber: Standard \& Poor’s - Corporate Ratings Criteria 2004

Tabel 5. Interpretasi Rating Menurut Standard \& Poor’s

\begin{tabular}{|c|l|}
\hline Rating & \multicolumn{1}{c|}{ Interpretasi } \\
\hline AAA & Kualitas tinggi - risiko minimum \\
\hline AA & Kualitas tinggi - risiko rendah \\
\hline A & Kualitas menengah tinggi - risiko cukup \\
\hline BBB & Kualitas menengah - risiko menengah \\
\hline BB & Kualitas menengah rendah - agak spekulatif \\
\hline B & Kualitas rendah - spekulatif \\
\hline CCC & Kualitas sangat rendah - spekulatif \\
\hline CC & Tingkat spekulatif tinggi, mendekati gagal \\
\hline C & Tidak bayar bunga \\
\hline DDD & Gagal \\
\hline
\end{tabular}

Sumber: Widioatmodjo, Sawidji (2005)

Adapun kriteria yang digunakan untuk menilai kinerja keuangan bank menurut Credit Analysis ialah seperti yang dijelaskan dalam tabel berikut:

Tabel 6. Kriteria Penilaian Kinerja Keuangan Bank Berdasarkan Credit Analysis

\begin{tabular}{ccc}
\hline Aspek & Kondisi & Keterangan \\
EBIT Interest Coverage & Meningkat & Semakin baik \\
Return on Capital & Meningkat & Semakin baik \\
Totat Debt to Capital & Menurun & Semakin baik \\
\hline
\end{tabular}




\section{Hasil Analisis}

\section{Kinerja keuangan BCA}

Tabel 7 Hasil Analisis Kinerja Keuangan Bank Central Asia

\begin{tabular}{|c|c|c|c|c|c|c|c|c|}
\hline \multirow{3}{*}{ Metode } & \multicolumn{6}{|c|}{ Diakuisisi Oleh Investor Asing } & \multirow{3}{*}{ Kondisi } & \multirow{3}{*}{ Keterangan } \\
\hline & \multicolumn{3}{|c|}{ Sebelum } & \multicolumn{3}{|c|}{ Sesudah } & & \\
\hline & 1995 & 1996 & $\begin{array}{c}\text { Rata- } \\
\text { rata }\end{array}$ & 2003 & 2004 & $\begin{array}{c}\text { Rata- } \\
\text { rata }\end{array}$ & & \\
\hline \multicolumn{9}{|l|}{ CAMELS: } \\
\hline CAR & $8.35 \%$ & $8.49 \%$ & $8.42 \%$ & $27.95 \%$ & $23.95 \%$ & $25.95 \%$ & Meningkat & Semakin baik \\
\hline NPL & $1.22 \%$ & $0.85 \%$ & $1.04 \%$ & $2.34 \%$ & $1.28 \%$ & $1.81 \%$ & Meningkat & Semakin buruk \\
\hline NIM & $2.29 \%$ & $2.65 \%$ & $2.47 \%$ & $4.93 \%$ & $5.28 \%$ & $5.11 \%$ & Meningkat & Semakin baik \\
\hline BOPO & $95.30 \%$ & $95.11 \%$ & $95.20 \%$ & $76.17 \%$ & $64.26 \%$ & $70.21 \%$ & Menurun & Semakin baik \\
\hline LDR & $61.55 \%$ & $68.61 \%$ & $65.08 \%$ & $24.62 \%$ & $30.60 \%$ & $27.61 \%$ & Menurun & Semakin buruk \\
\hline \multicolumn{9}{|l|}{$\begin{array}{c}\text { Profitability } \\
\text { Analysis: }\end{array}$} \\
\hline NPM & $3.61 \%$ & $3.59 \%$ & $3.60 \%$ & $17.67 \%$ & $24.42 \%$ & $21.04 \%$ & Meningkat & Semakin baik \\
\hline ROE & $7.63 \%$ & $10.01 \%$ & $8.82 \%$ & $18.94 \%$ & $22.95 \%$ & $20.94 \%$ & Meningkat & Semakin baik \\
\hline $\mathrm{ROA}$ & $0.45 \%$ & $0.48 \%$ & $0.46 \%$ & $1.80 \%$ & $2.15 \%$ & $1.97 \%$ & Meningkat & Semakin baik \\
\hline \multicolumn{9}{|l|}{$\begin{array}{l}\text { Credit } \\
\text { Analysis: }\end{array}$} \\
\hline $\begin{array}{c}\text { EBIT } \\
\text { Interest } \\
\text { Coverage }\end{array}$ & $\begin{array}{c}0.08 x \\
(\mathrm{CCC})\end{array}$ & $\begin{array}{c}0.06 x \\
(\mathrm{CCC})\end{array}$ & $\begin{array}{c}0.07 x \\
(\mathrm{CCC})\end{array}$ & $\begin{array}{c}0.46 x \\
(\mathrm{CCC})\end{array}$ & $\begin{array}{c}0.93 x \\
(\mathrm{CCC})\end{array}$ & $\begin{array}{c}0.69 x \\
(\mathrm{CCC})\end{array}$ & Tetap & Stabil \\
\hline $\begin{array}{l}\text { Return on } \\
\text { Capital }\end{array}$ & $\begin{array}{l}0.7 \% \\
(\mathrm{CC})\end{array}$ & $\begin{array}{l}0.7 \% \\
\text { (CC) }\end{array}$ & $\begin{array}{c}0.70 \% \\
\text { (CC) }\end{array}$ & $\begin{array}{c}2.35 \% \\
\text { (CC) }\end{array}$ & $\begin{array}{c}3.03 \% \\
\text { (CC) }\end{array}$ & $\begin{array}{c}2.69 \% \\
\text { (CC) }\end{array}$ & meningkat & Semakin baik \\
\hline $\begin{array}{c}\text { Total Debt to } \\
\text { Capital }\end{array}$ & $\begin{array}{c}94.2 \% \\
(\mathrm{CC})\end{array}$ & $\begin{array}{c}95.2 \% \\
(\mathrm{CC})\end{array}$ & $\begin{array}{l}94.7 \% \\
(\mathrm{CC})\end{array}$ & $\begin{array}{c}90.50 \% \\
\text { (CCC) }\end{array}$ & $\begin{array}{c}90.64 \% \\
\text { (CCC) }\end{array}$ & $\begin{array}{c}90.57 \% \\
(\mathrm{CCC})\end{array}$ & Menurun & Semakin baik \\
\hline
\end{tabular}

Kinerja BCA berdasarkan rasio CAMEL menunjukkan terjadi perbaikan kecuali di rasio NPL dan LDR. Sebelum diakuisisi oleh investor asing NPL BCA dapat dikategorikan lebih rendah yakni sebesar 1.22\% pada tahun 1995 dan 0.85\% pada tahun 1996, dibandingkan dengan setelah diakuisisi oleh investor asing yakni $2.34 \%$ pada tahun 2003 dan 1.28\% pada tahun 2004. Namun, tingkat NPL BCA ini masih tergolong baik karena tidak melebihi batas maksimum yang ditetapkan oleh BI, yakni 5\%. Dari segi LDR, sebelum diakuisisi oleh investor asing ialah sebesar $61.55 \%$ dan $68.61 \%$ pada tahun 1995 dan 1996. Pada tahun 2003 terjadi penurunan menjadi 24.62\%. Meskipun sedikit, namun ada tahun 2004, LDR bank kembali naik menjadi 30.60\%. Diasumsikan bahwa bank masih sangat berhati-hati dalam memberikan kredit kepada masyarakat pasca krisis ekonomi yang terjadi pada akhir tahun 1997, sehingga jumlah kredit yang diberikan tergolong rendah dibandingkan depositnya. Namun LDR BCA terus meningkat secara perlahan seiring pulihnya kondisi ekonomi nasional hingga mencapai 55.2\% di tahun 2010. Ditinjau dari profitabilitasnya, kinerja BCA semakin baik begitu pula dengan resiko kreditnya yang stabil. 


\section{Kinerja Keuangan Bank Niaga}

Tabel 8. Hasil Analisis Kinerja Keuangan Bank Niaga

\begin{tabular}{|c|c|c|c|c|c|c|c|c|}
\hline \multirow{3}{*}{ Metode } & \multicolumn{6}{|c|}{ Diakuisisi Oleh Investor Asing } & \multirow{3}{*}{ Kondisi } & \multirow{3}{*}{ Keterangan } \\
\hline & \multicolumn{3}{|c|}{ Sebelum } & \multicolumn{3}{|c|}{ Sesudah } & & \\
\hline & 1995 & 1996 & $\begin{array}{c}\text { Rata- } \\
\text { rata }\end{array}$ & 2003 & 2004 & $\begin{array}{c}\text { Rata- } \\
\text { rata }\end{array}$ & & \\
\hline \multicolumn{9}{|l|}{ CAMELS: } \\
\hline CAR & $8.27 \%$ & $10.75 \%$ & $9.51 \%$ & $11.58 \%$ & $10.29 \%$ & $10.94 \%$ & Meningkat & Semakin baik \\
\hline NPL & $0.89 \%$ & $1.14 \%$ & $1.01 \%$ & $3.61 \%$ & $3.18 \%$ & $3.40 \%$ & Meningkat & Semakin buruk \\
\hline NIM & $4.51 \%$ & $5.01 \%$ & $4.76 \%$ & $4.59 \%$ & $5.36 \%$ & $4.98 \%$ & Meningkat & Semakin baik \\
\hline BOPO & $90.60 \%$ & $88.75 \%$ & $89.68 \%$ & $88.78 \%$ & $79.41 \%$ & $84.09 \%$ & Menurun & Semakin baik \\
\hline LDR & $93.83 \%$ & $105.21 \%$ & $99.52 \%$ & $72.82 \%$ & $85.28 \%$ & $79.05 \%$ & Menurun & Semakin baik \\
\hline \multicolumn{9}{|l|}{ Profitability } \\
\hline NPM & $7.54 \%$ & $9.42 \%$ & $8.48 \%$ & $16.93 \%$ & $22.17 \%$ & $19.55 \%$ & Meningkat & Semakin baik \\
\hline ROE & $21.17 \%$ & $15.96 \%$ & $18.57 \%$ & $23.66 \%$ & $27.94 \%$ & $25.80 \%$ & Meningkat & Semakin baik \\
\hline ROA & $1.02 \%$ & $1.33 \%$ & $1.18 \%$ & $1.98 \%$ & $2.16 \%$ & $2.07 \%$ & Meningkat & Semakin baik \\
\hline \multicolumn{9}{|l|}{ Credit Analysis: } \\
\hline $\begin{array}{l}\text { EBIT Interest } \\
\text { Coverage }\end{array}$ & $\begin{array}{c}0.16 \mathrm{x} \\
(\mathrm{CCC}) \\
1.4 \%\end{array}$ & $\begin{array}{c}0.21 \mathrm{x} \\
\text { (CCC) } \\
1.9 \%\end{array}$ & $\begin{array}{c}0.18 x \\
(\mathrm{CCC}) \\
1.6 \%\end{array}$ & $\begin{array}{c}0.32 \mathrm{x} \\
(\mathrm{CC}) \\
1.87 \%\end{array}$ & $\begin{array}{c}0.67 x \\
(\mathrm{CCC}) \\
2.45 \%\end{array}$ & $\begin{array}{c}0.49 x \\
(\mathrm{CCC}) \\
2.16 \%\end{array}$ & Meningkat & Semakin baik \\
\hline Return on Capital & (CCC) & (CCC) & (CCC) & (CC) & (CC) & (CC) & Meningkat & Semakin baik \\
\hline $\begin{array}{l}\text { Total Debt to } \\
\text { Capital }\end{array}$ & $\begin{array}{c}95.2 \% \\
\text { (CC) }\end{array}$ & $\begin{array}{l}91.6 \% \\
\text { (CC) }\end{array}$ & $\begin{array}{c}93.40 \% \\
\text { (CC) }\end{array}$ & $\begin{array}{l}91.64 \% \\
\text { (CCC) }\end{array}$ & $\begin{array}{c}92.29 \% \\
\text { (CCC) }\end{array}$ & $\begin{array}{l}91.96 \% \\
\text { (СCC) }\end{array}$ & Menurun & Semakin baik \\
\hline
\end{tabular}

Kinerja Bank Niaga berdasarkan rasio CAMEL menunjukkan terjadi perbaikan kecuali di rasio NPL. Jumlah kredit bermasalah yang dimiliki oleh Bank Niaga sebelum diakuisisi oleh investor asing dapat dikategorikan lebih rendah yakni sebesar 0.89\% pada tahun 1995 dan 1.14\% pada tahun 1996, dibandingkan dengan setelah diakuisisi oleh investor asing yakni 3.61\% pada tahun 2003 dan 3.18\% pada tahun 2004. Namun, tingkat NPL Bank Niaga ini masih tergolong baik karena tidak melebihi batas maksimum yang ditetapkan oleh BI, yakni 5\%. Ditinjau dari profitabilitasnya, kinerja Bank Niaga semakin baik begitu pula dengan resiko kreditnya yang tetap stabil.

\section{PENUTUP}

Berdasarkan hasil penelitian yang telah dilakukan, maka peneliti menyimpulkan bahwa menurut CAMELS, dinilai dari CAR, NIM, maka baik BCA maupun Bank Niaga menunjukkan tingkat kinerja keuangan yang semakin baik. Begitupula BOPO untuk kedua bank tersebut mengalami penurunan yang mengindikasikan bahwa biaya mengecil sesudah diakuisisi oleh investor asing dibandingkan dengan sebelum akuisisi. Namun kinerja yang kurang bagus dalam NPL dan LDR untuk BCA dan NPL yang kurang bagus untuk Bank Niaga. Dari segi profitability Analysis yang dinilai dari ketiga aspek secara keseluruhan, yakni NPM, ROE, dan ROA maka baik BCA maupun Bank Niaga menunjukkan tingkat kinerja keuangan yang semakin baik, yakni mengalami peningkatan dibandingkan sebelum diakuisisi oleh investor asing. Sedangkan menurut Credit Analysis, dinilai dari ketiga aspek secara keseluruhan, yakni EBIT Interest Coverage, Return on Capital, dan Total Debt to Capital, maka kedua bank yaitu BCA dan Bank Niaga menunjukkan risiko kredit yang cenderung stabil menempati peringkat CCC menurut Standard \& Poor's. 
Adapun keterbatasan yang dihadapi oleh penulis dalam melakukan studi ini adalah periode penelitian yang relatif pendek sehingga variabel yang digunakan dalam metode penelitian pun tergolong relatif sedikit, padahal masih banyak metode / analisis / rasio lain yang dapat digunakan dalam meneliti seperti analisis secara statistik. Selain itu, peneliti juga mengalami kesulitan dalam memperoleh data maupun referensi, terutama untuk periode penelitian sebelum bank diakuisisi oleh investor asing yakni tahun 1995 dan 1996, sehingga data dan referensi yang diperoleh pun terbatas dan kurang memadai untuk meneliti kinerja bank dengan menggunakan metode CAMELS dan Credit Analysis yang sesuai dengan standar BI dan Standard \& Poor's.

\section{DAFTAR PUSTAKA}

Akbarwati, I (2010). Peta perbankan Indonesia berkenaan penerapan API. Diakses tanggal 24 Februari 2011.

http://www.managementfile.com/column.php?sub=economy\&id=2080\&page=economy

Asian Development Bank (2004). Second Development Finance Project (Loan 1223-INO) in Indonesia. http://www.adb.org/Documents/PPARS/INO/ppar-ino-26194.pdf. Diakses tanggal 21 Mei 2011.

Bonin, J. P., Hasan, I., \& Wachtel, P. (2003). Bank performance, efficiency and ownership in transition countries. Paper dipresentasikan pada The Ninth Dubrovnik Economic Conference, Hotel Argentina, Dubrovnik, June 26-28, 2003.

Chantapong, S. (2005). Comparative study of domestic and foreign bank performance in thailand: The regression analysis. Economic Change and Restructuring, 38: 63-83.

Farid. (1996). Obligasi RI: MenKeu Tak Risaukan Peringkat S\&P. http://www.kompas.com/perubahankondisiekonomi.9607/23/UTAMA/menk.htm. Diakses tanggal 6 Juni 2011.

Kashmir. (2008). Manajemen perbankan (edisi revisi 2008). Jakarta: RajaGrafindo Persada.

Surat Edaran No. 6/23/DPNP tanggal 31 Desember 2004, Tentang Pedoman perhitungan rasio keuangan.

Surat Keputusan Direksi No. 6/10/PBI/2004 tanggal 12 April 2004, Tentang Tata cara penilaian tingkat kesehatan bank umum.

Suta, I. P. G. A., \& Soebowo, M. (2003). Membedah krisis perbankan; Anatomi krisis dan penyehatan perbankan. Jakarta: Yayasan SAD Satria Bhakti.

Widioatmodjo, S. (2005). Cara sehat investasi pasar modal. Jakarta: Elex Media Komputindo. 